\title{
Human-bat interactions in central Colombia: Regional perceptions of a worldwide fragile life zone
}

\author{
Leidy Azucena Ramírez-Fráncel ${ }^{1 *}{ }^{(0)}$, Leidy Viviana García-Herrera ${ }^{1}$ (i), \\ Giovany Guevara ${ }^{2}$ (1), Sergio Losada-Prado ${ }^{2}$, Burton K. Lim ${ }^{3}$ (1), \\ Francisco Antonio Villa-Navarro ${ }^{2}$ and Gladys Reinoso-Flórez ${ }^{2}$
}

\begin{abstract}
The study of human relationships with other components of the landscape allows us to understand the dynamics of ecological communities and biodiversity. Although there has been an increase in ethnobiological studies, little is known about the interaction between humans and bats. The objective of this study was to evaluate the perceptions and attitudes about bats by people in the fragile life zone of the tropical dry forest of Colombia. We selected four representative areas and evaluated three different aspects: (1) biological and ecological knowledge, (2) uses and cultural beliefs, and (3) interactions between humans and bats. The data were collected through surveys of 18 questions to 197 people with a gender ratio close to parity. The data obtained are presented as descriptive statistics by using a generalized linear model (GLM). The results showed that people's knowledge and attitude towards bats depend on the covariates of education and gender of the respondents. Women and people with a higher education level had positive attitudes towards bats. Although the ecosystem services provided by bats were clearly recognized, the need for conservation was not as obvious. These results indicate that human-bat relationships are complex and may be the result of multiple social and cultural factors. Likewise, these cross-cultural perceptions must be understood and addressed in the development of actions that promote the conservation of bats in tropical forests.
\end{abstract}

Keywords: Bats; Ethnoconservation; Ethnozoology; Tropical dry forests; Human-wildlife conflicts; Local perception; Nature conservation.

\footnotetext{
1 Ph.D(c), Facultad de Ciencias, Departamento de Biología, Grupo de Investigación en Zoología (GIZ), Universidad del Tolima. Ibagué, Tolima, Colombia.

2 Docente, Facultad de Ciencias, Departamento de Biología, Grupo de Investigación en Zoología (GIZ), Universidad del Tolima. Ibagué, Tolima, Colombia.

3 Department of Natural History, Royal Ontario Museum, 100 Queen's Park, Toronto, Ontario M5S 2C6, Canada.

* Corresponding author $\bowtie$. E-mail address: LAR-F (laramirezfr@ut.edu.co)
} 


\section{SIGNIFICANCE STATEMENT}

Tropical forests represent key areas covering less than $7 \%$ of the global land surface and host nearly half of all terrestrial species. Despite their great importance, several gaps persist, mainly related to the tropical dry forest (TDF) from an ethnobiological perspective. These habitats also face the greatest threat from human overexploitation, destruction, or modification, and by global climate change. The TDF harbor many important animal species such as bats, which provide multiple ecosystem services, including seed dispersal, flower pollination, and insect control. However, bats are poorly known with many negative myths and misconceptions about them. Here, we highlight the main results of human-bat interactions from representative areas of the last TDF remnants in the Department of Tolima in central Colombia. Our results will contribute to the conservation of bats in Colombia and by extension to the global TDF remnants and reduce further conflicts between people and these unique flying mammals.

\section{INTRODUCTION}

Mammals are a recurring theme in the rock pictograms, sculptures, ceramics and goldsmithing of almost all the pre-Columbian cultures and they significantly nurture the legacy of the oral tradition of the multiple ethnic groups that have inhabited Colombia (Mantilla-Meluk et al. 2014). The pre-Hispanic civilization of the country, as well as that of other cultures in the Americas, shows the importance of bats both through myths and ceremonial rituals (RetanaGuiascón and Navarijo-Ornelas 2012). For example, in the mythology of the Kogi people in northern Colombia, the image of the bat is deified and associated with the sun personifying human-animal hybridization through ritual masks. Peoples of the Sierra Nevada de Santa Marta, as well as those from the central region of the country, depict bat characters such as the noseleaf and the shape of the ears in their jewelry, headdresses, and nose and ear pendants (Gault 2012).

Although the worldview of pre-Hispanic peoples highlights the value of bats, medieval European societies position them as an archetype of evil or the incarnation of the devil, generating community narratives of horror and fear (Castro and Galindo 2009). These perceptions reached the American continents during the colonial era where similar legends became established (Retana-Guiascón and Navarijo-Ornelas 2012). Later, the influence of cinema with the personification of Dracula and the relationship with the consumption of blood further generated a negative image within the community. This influence increases the human-bat conflicts because the simplest action to avoid encounters is killing the bats (even for non-hematophagous species). This is one of the main threats to the bat populations in Colombia, and negatively affects the perceptions about their vital ecological roles in the ecosystems (Moya et al. 2015; Ramírez-Fráncel et al. 2021; Torres and Fernández 2012). Therefore, to conserve bats in landscapes with human presence and activity requires better empirical support and a greater understanding of human-bat interaction. Other posi- tive impacts of social or community interaction is the inclusion of a large amount of information, including technical data on environmental issues (Dichdji 2017).

Ethnobiological studies are an essential tool to initiate conservation plans and environmental education for key species and/or vulnerable areas elsewhere (Alves and Souto 2015; Burneo et al. 2015). Cultures across the world since ancient times have developed characteristic ways of interacting with their regional biota (Alves 2012; Albuquerque et al. 2020). Likewise, the associated ethnozoological research constitutes an excellent way to establish the clear relationships between fauna and people (Alves 2012). For some years in Colombia, these studies have been carried out mainly related to large and medium mammals with high economic value (De la Ossa-Lacayo and De la Ossa 2012a; 2012b; Osbahr and Morales 2012; Parra et al. 2015). By contrast, small mammals such as bats have been commonly ignored, despite their high biodiversity. Colombia is one of the most diverse countries with 217 species of bats, comprising almost $40 \%$ of the total species registered for South America (Rodríguez-Posada et al. 2021). The functional role that bats play becomes a component essential to the Neotropical forest dynamics because they contribute to the maintenance of environmental stability through ecosystem provisioning and regulating services such as insect pest control, pollination, seed dispersal, and production of guano as plant fertilizer. These are essential mechanisms for the dynamics of forested or cultivated areas and indicators of the state of health of the forests (Kunz et al. 2011; Melathopoulos et al. 2015; Millennium Ecosystem Assessment 2005; Ramírez-Fráncel et al. 2021; Van Toor et al. 2019).

At a worldwide scale, tropical dry forest (hereafter TDF) harbors about $40 \%$ of all tropical forests. However, this key global life zone is currently facing heavy risks both from human-induced and natural modifying factors (Siyum 2020). In Colombia, the TDF is among the three most degraded, fragmented and least known ecosystems (Pizano et al. 2014). This lack of knowledge, particularly in the Department of Tolima 
(central part of the country), limits the processes and actions for the establishment of sustainable use, conservation, and restoration of the TDF, and its associated biodiversity (García-Herrera et al. 2020; Torres and Fernández 2012).

The TDF in Tolima represents a biodiversity hot spot, not only because it harbors $44 \%$ of the bat species regionally registered (56 spp. associated to the TDF life zone in Colombia) and 26\% from those for Colombia (García-Herrera et al. 2019a), but also in cultural wealth. Different human groups coexisted from prehistory to the present, who lived through different demographic processes (Alonso Morales 2013; Alonso Morales et al. 2020), with a variety of beliefs, values, and customs. The communities that inhabit these areas are immersed in a fragmented (agro)ecosystem surrounded by natural areas of great importance because of the biodiversity and ecosystem services that wildlife, including bats provide (GarcíaHerrera et al. 2015; Ramiírez-Fráncel et al. 2015). However, there is a general ignorance of the state of the TDF and the fauna it harbors. In addition, the human perception and knowledge of bats, and attitudes and actions towards them needs to improve in order to establish policies that lead to their conservation (García-Herrera et al. 2020).

The objectives of this research were to assess the knowledge and perception of the people living in tropical dry forest fragments about bats related to three different aspects: (1) biological and ecological knowledge, (2) use and cultural beliefs, and (3) human-bat interactions. In this way, we propose an initial approach to the relationship between the human community and the species of bats that inhabit this territory in central Colombia.

\section{MATERIAL AND METHODS}

\section{Study area}

The Department of Tolima $\left(23,562 \mathrm{~km}^{2}\right)$ is located in the trans-Andean region of Colombia, in the upper basin of the Magdalena River. This territory comprises the slopes and high Andean mountains that form the Central and Eastern Cordilleras (mountain chains) and the dry-Magdalena inter-Andean valley (Salgado López and Varón Barbosa 2019). The Department of Tolima has a population of 1,330,187 inhabitants, of which $93.15 \%$ belong to a Mestizo community (racially/culturally mixed), $5.61 \%$ to Indigenous people, $1.21 \%$ to Afro-Colombians and $0.03 \%$ to a Romani population. This last ethnic group is made up of 19 households with a total of 49 people belonging to traditionally nomadic itinerants of Indo-Aryan origin known as clan or vitsi Bolochov - Kumpania del Tolima (Gobernación del Tolima and Universidad del Tolima 2016).

Population genetic studies have shown that the upper valley of the Magdalena River is inhabited by Indigenous groups such as Coyaima, Pijao, and Nasa (Porras et al. 2008). By 1537, during the period of Spanish colonization of the Americas, African and Hispanic people were also in the area. Studies using molecular markers and sociocultural variables have determined that the population of the upper valley of the Magdalena River has experienced ongoing migration due to armed conflicts that dominate Colombia's recent history and the search for new opportunities in employment or study (Alonso Morales 2013; Alonso Morales et al. 2018; Rojas et al. 2010).

We selected study sites in the northern and central region of the Department of Tolima based on information of ethnic group distribution and occurrence of tropical dry forest habitats. Sites were located in the municipalities of Alvarado $\left(311.15 \mathrm{~km}^{2} ; 8,796\right.$ inhabitants; $439 \mathrm{~m}$ a.s.l.), Ambalema (239 km²; 6,683 inhabitants; $241 \mathrm{~m}$ a.s.l.), Armero-Guayabal (440.5 $\mathrm{km}^{2}$; 11,724 inhabitants; $285 \mathrm{~m}$ a.s.l.), Ibagué (1,498 $\mathrm{km}^{2} ; 529,635$ inhabitants; $1.285 \mathrm{~m}$ a.s.l.) and San Sebastián de Mariquita (379.52 $\mathrm{km}^{2}$; 33,340 inhabitants; $495 \mathrm{~m}$ a.s.l.) (Figure 1).

The total population of the communities studied fluctuated around 1,800 inhabitants, of which only $17 \%$ are considered community members. They are holders of agrarian rights, which allows them to access the use and enjoyment of a plot of land and decide on the use and benefit of the common goods of a community. The communities in this study have been considered highly marginalized due to the precarious standard of living, their low education level and because they lack most basic services (Gobernación del Tolima and Universidad del Tolima 2016). The main economic activity of the study populations is agriculture, mainly corn, rice, sorghum, cotton, and forest systems, which are used for self-consumption. The cultivation of rice and cotton are essential because in most cases it is one of the most important sources of income for families.

\section{Data collection}

During 2015-2019, street surveys and observations were conducted following Drumond et al. (2009) with local inhabitants living in Alvarado, Ambalema, Armero-Guayabal, Ibagué and San Sebastián de Mariquita. Each survey consisted of 18 semistructured questions (Table 1) related to bat biology, ecology, use, cultural beliefs and human interactions. The methodological approach was in accordance with the Code of Ethics of the International Society of Ethnobiology (2006). Participants' consent was obtained before interviewing them. The ethnic origin of the 


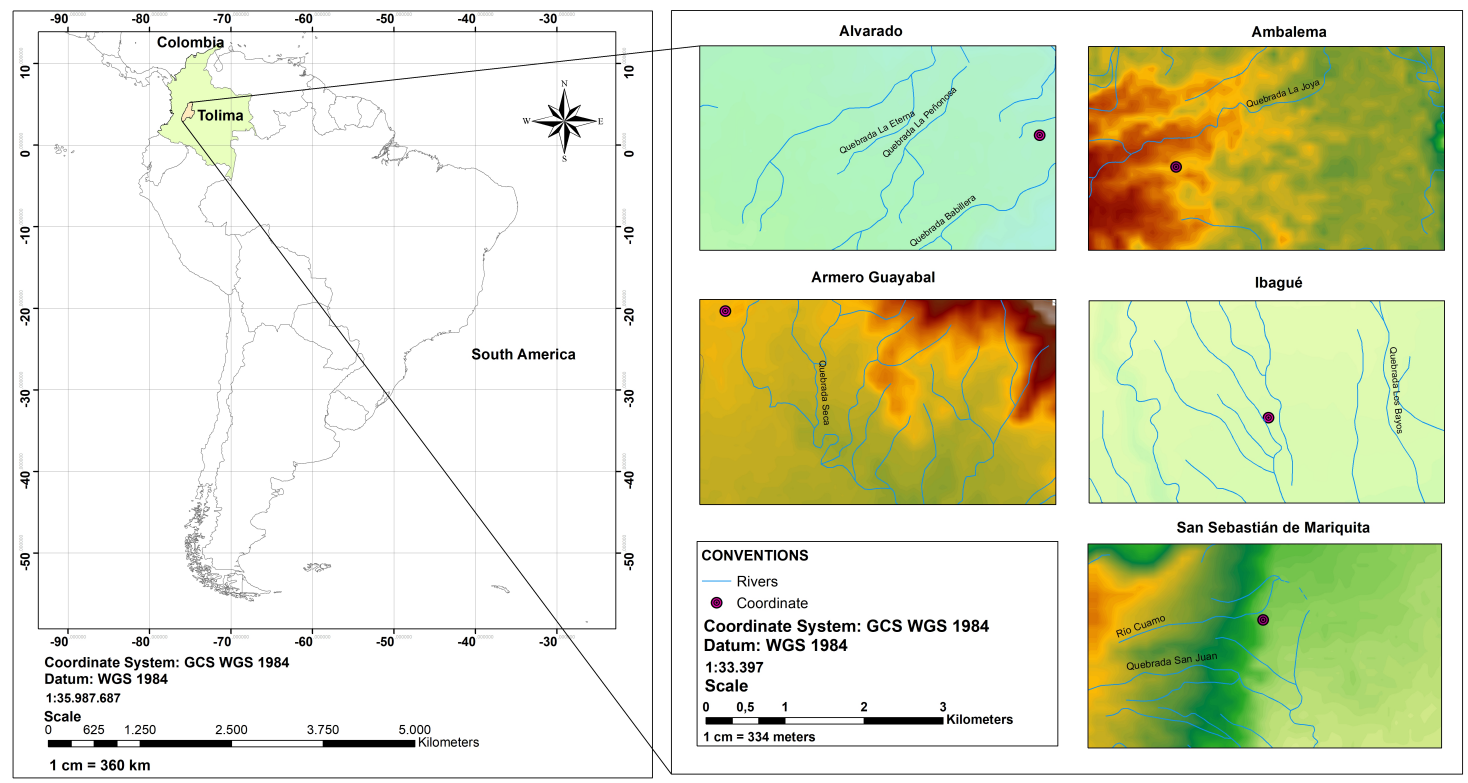

Figure 1. Location of the selected areas (municipalities) in the Department of Tolima (Colombia) for the study of human-bat interactions.

people was classified based on the regional Government information (Gobernación del Tolima and Universidad del Tolima, 2016): as Mestizo, Indigenous, Afro-descendant or Romani. In addition, gender, age, education level (primary, basic, high school, technical or undergraduate), and type of work (farmers, rice farm workers, fishermen, company employees and housewives) were recorded.

\section{Analysis of data}

The data were analyzed using descriptive statistics that take into account an ethnozoological approach (Albuquerque et al. 2016). For the analysis of per- ception and attitude, we used a semi-parametric regression approach, based on Generalized Linear Models - GLM (Rigby and Stasinopoulos 2005). We used a model with 22 covariates, represented by the number of questions in the survey. Gender, age, ethnic origin, educational level and type of work were used as fixed covariates (see Table 2) and the remaining questions as random covariates. All statistical analyses were performed in $\mathrm{R}$ version 4.0.2 ( $\mathrm{R}$ Core Team 2020), using the packages "gamlss.dist", "MASS", and "gamlss" and specifying a binomial distribution. We used a paired t-test to compare and evaluate the tendency to a positive or negative attitude of the inhabitants towards bats. 
Table 1. Questionnaire and response of the interviewees on human-bat interactions in Tolima, Colombila. 필 侮

\begin{tabular}{|c|c|c|c|c|c|}
\hline \multirow{2}{*}{ Questionnaire } & \multicolumn{5}{|c|}{$\begin{array}{l}\text { Localities } \\
\end{array}$} \\
\hline & Alvarado & Ambalema & Armero Guayabal & Ibagué & San Sebastián de Mariquita \\
\hline \multicolumn{6}{|c|}{ Biology and ecology of bats } \\
\hline \multicolumn{6}{|c|}{ Do you know bats? } \\
\hline Yes & 39 & 37 & 37 & 38 & 43 \\
\hline No & & 1 & & 2 & \\
\hline \multicolumn{6}{|c|}{ What is the taxonomic position of bats? } \\
\hline Mice & 13 & 13 & 5 & 9 & 10 \\
\hline Birds & 10 & 7 & 10 & 12 & 16 \\
\hline Mammals & 14 & 10 & 17 & 15 & 17 \\
\hline Reptiles & 2 & 8 & 5 & 4 & \\
\hline \multicolumn{6}{|c|}{ What do bats eat? } \\
\hline Fruit & 8 & 12 & 9 & 13 & 12 \\
\hline Inset & 11 & 8 & 16 & 16 & 17 \\
\hline Nectar & 1 & & 2 & 3 & \\
\hline Mice & 5 & 3 & 1 & & \\
\hline Blood & 14 & 15 & 9 & 10 & 12 \\
\hline \multicolumn{6}{|c|}{ What color are bats? } \\
\hline Black & 18 & 16 & 17 & 18 & 13 \\
\hline Gray & 4 & 14 & & 9 & 26 \\
\hline \multicolumn{6}{|l|}{ Orange } \\
\hline \multicolumn{6}{|l|}{ White } \\
\hline Red & & & 1 & & \\
\hline Brown & 17 & 3 & 15 & 13 & 4 \\
\hline Other & & 5 & 4 & & \\
\hline \multicolumn{6}{|c|}{ How many species of bats do you think live in nearby forests? } \\
\hline 1 & & 18 & 20 & 18 & 21 \\
\hline 3 & 21 & 5 & 11 & 14 & 13 \\
\hline 5 & 7 & 6 & 6 & 6 & 1 \\
\hline 10 & 11 & 8 & & 2 & 8 \\
\hline 15 & & 1 & & & \\
\hline$>15$ & & & & & \\
\hline
\end{tabular}

\begin{tabular}{lccccc} 
& Use and cultural beliefs & & \\
\hline What kinds of diseases do bats transmit? & & & & \\
Rabies virus & 25 & 14 & 22 & 16 & 10 \\
Different viruses and bacteria & 12 & 19 & 5 & 4 & 25
\end{tabular}


Where do bats live?

Human constructions

22

Caves

Trees

Banana leaves

Others

What do bats do for the ecosystem?

Controlling insects

Seed dispersa

Flower pollination

Regulation of vertebrate populations

Nothing

Do you consider bats to be blind?

Yes

No

What uses do you know of bats?

Guano as fertilizer

None

Treatment for asthma

$\begin{array}{cc}11 & 16 \\ 9 & 14 \\ 1 & \\ 14 & 4 \\ 4 & 4 \\ 17 & 14 \\ 22 & 24 \\ & \\ 11 & 9 \\ 27 & 29\end{array}$

What degree of closeness have you had with a bat?

Have touched it

Live with them at home

Live with them at work

$\begin{array}{cc}8 & 2 \\ 12 & 13\end{array}$

They visit a tree in their house

Never had them around

tions

If you have touched a bat, you have touched it using:

A broom $25 \quad 12$

A plastic bag

Have worn gloves

Without protection

With a clamp

What do you feel when you see a bat?

I don't know, not sure

They are scary, ugly

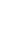

Bats are part of nature

Demons

Harmful animals 
How have bats been extracted from human structures?

Smoke

11

Burning oil

With a broom

With a rag

Closing entries

Turned on the light

Doing nothing

How do you perceive bats?

Ugly

Bats are a part of nature and nice

Do not bother

What damage do bats cause?

Suck the blood of farm animals

Get tangled in hair

They are bad luck

Cause damage or eat fruits

They do not cause anything

8

hat myths do you know

Product of God and the devil

They are blind

They smoke

$15 \quad 9$

9

ated to bats?

What animals in your area should be conserved?

Oncilla (Leopardus tigrinus)

Birds

Night monkey (Aotus lemurinus) 
Table 2. Fixed covariates used in the Generalized Linear Models (GLM) of human-bat interactions in Tolima, Colombia.

\begin{tabular}{|c|c|c|c|c|c|c|c|c|c|c|c|c|c|c|c|c|c|c|c|c|c|c|c|c|c|c|c|}
\hline \multirow[t]{2}{*}{ Variable } & \multicolumn{6}{|c|}{ Women* } & \multicolumn{6}{|c|}{ Men* } & \multicolumn{4}{|c|}{$\begin{array}{c}\text { Ethnic } \\
\text { origin** }\end{array}$} & \multicolumn{5}{|c|}{$\begin{array}{c}\text { Education } \\
\text { level*** }\end{array}$} & \multicolumn{6}{|c|}{$\begin{array}{c}\text { Туре } \\
\text { of job**** }\end{array}$} \\
\hline & 1 & 2 & 3 & 4 & 5 & 6 & 1 & 2 & 3 & 4 & 5 & 6 & 1 & 2 & 3 & 4 & 1 & 2 & 3 & 4 & 5 & 1 & 2 & 3 & 4 & 5 & 6 \\
\hline Alvarado & 5 & 4 & 3 & 8 & & & 4 & 7 & & & 8 & & 1 & 2 & & 37 & 21 & 9 & 3 & 4 & 2 & & 13 & 4 & 11 & 11 & \\
\hline Ambalema & & 12 & 1 & & 6 & & 5 & & 13 & & 1 & & 2 & & & 36 & 22 & 9 & 1 & 3 & 3 & 4 & 5 & & 12 & 17 & \\
\hline Armero Guayabal & 2 & & 5 & 9 & 4 & & & 8 & 7 & & 2 & & & & 2 & 34 & 22 & 9 & 3 & 1 & 2 & & 6 & 7 & 9 & 15 & \\
\hline Ibagué & 5 & 6 & & 1 & 8 & & 3 & 3 & 4 & 9 & 1 & & & 1 & 4 & 35 & 14 & & 14 & 7 & 5 & & 11 & & & 19 & 10 \\
\hline Mariquita & 1 & 3 & 4 & & 9 & 3 & 2 & & 9 & 7 & 5 & & 4 & & & 39 & 18 & 9 & 10 & 2 & 4 & & & & & 18 & 25 \\
\hline
\end{tabular}

\begin{tabular}{lllll}
\hline \hline & $*$ Age & $* *$ Ethnic origin & $* * *$ Education level & $* * * *$ Type of job \\
\hline \hline 1 & $18-30$ & Afro & Primary & Farmers \\
2 & $31-43$ & Romani & Basic $\left(\right.$ up to $\left.9^{\circ}\right)$ & Jobs related to rice cultivation \\
3 & $44-56$ & Indigenous & High school & Fishermen \\
4 & $57-69$ & Mestizo & Undergraduate & Housewife \\
5 & $70-82$ & & Technical & Different jobs \\
6 & $83>$ & & Do not work & \\
\hline \hline
\end{tabular}




\section{RESULTS AND DISCUSSION}

\section{Community interviews}

We surveyed 39 people from Rincón de Chipalo (Alvarado), 38 from San Felipe (Armero Guayabal), 37 from Chorrillo (Ambalema), 40 from Aparco (Ibagué) and 43 from José Celestino Mutis (San Sebastián de Mariquita) for a total of 197 interviewees, who were between 18 and 89 years old with a sex ratio close to $1: 1$. In terms of ethnic origin, $91.88 \%$ of the surveyed population were Mestizo, $3.55 \%$ Afrodescendants, $3.04 \%$ Indigenous, and $1.53 \%$ Romani (Table 2).

Colombia has one of the most diverse populations in Latin America, with contributions from three main continental groups: Europeans, Africans, and indigenous Americans (Rondón et al. 2008). The highest concentration of racially mixed ancestry is mainly in urban areas, particularly in the Andean region, including the Department of Tolima (Rojas et al. 2010). Local migrations and socio-cultural interactions have resulted in the current population comprised of Mestizo, Indigenous, Afro-descendant and Roma people, which have their own cultural roots, customs, and ideologies, as well as their own perspective of territory, nature, and animals (Cimadamore 2006). This vision about nature can have important implications for the conservation of bats exclusive of government initiatives because a large part of the territories where these species occur are communal property and belong to ejidos or Indigenous communities. Undoubtedly, the conservation of biodiversity in communal lands involves local people and implies values, local knowledge, culture, social perception about the nature of the environment and conservation actions that are carried out where they already exist (Berkes 2008; Ramos et al. 2007). However, there are few studies on bats that simultaneously analyze the human dimension and the human-bat interaction in communal lands, beyond pointing out conflicts and risk with these species, which is common in other places of the world (Prokop and Randler 2018; Torres et al. 2018). Therefore, it is of great cultural value to know the perception and use of bats as part of nature within these local communities.

The structured interviews had as elements the registry of each community (the level of education, gender, and ethnic origin) to recognize the perception, attitudes and local knowledge about bats. For education, 97 (49\%) people had incomplete primary school, $36(18 \%)$ with education up to the ninth grade, 31 (16\%) completed secondary education, 17 (9\%) completed some undergraduate university study, and the remaining $16(8 \%)$ had technical studies in production and service sectors. For work, 80 (41\%) had per- manent employment, 35 (18\%) had temporary jobs or did not work, $32(16 \%)$ were housewives, $11(6 \%)$ were fishermen, 35 (17\%) had jobs related to rice cultivation, and $4(2 \%)$ were farmers (Table 2$)$.

The GLM showed that all the fixed-effect covariates used, except for origin of people (municipality), determined or was related to the response with a significance $P<0.05$ and AIC: 176291.4. For the degree of knowledge about bats, 194 individuals (98.5\%) stated that they had seen a bat and only $3(1.5 \%)$ of the respondents stated that they had never seen bats.

\section{Local knowledge about bats}

Regarding the taxonomic relationship of bats, 124 $(62.9 \%)$ people did not recognize bats, instead incorrectly assuming that bats are birds because they fly or rodents due to their morphological similarity (Figure 2a). The variation of the responses regarding the taxonomic position of the bats was significantly affected by the level of education $(\mathrm{t}=10.39 ; \mathrm{P}$ $<0.002$, Table 3 ). The variables that significantly explained most of the variation level of education were: Primary and Basic (up to 9th grade). In a similar ethnobiological study, Drummond (2004) noted that $13 \%$ of respondents said that bats were insects, and $12 \%$ of respondents considered bats as rats. Gomes et al. (2017) reported a similar pattern in an ethnozoological study conducted in Brazil.

For the feeding habits of bats, insectivorous was the most common response with 68 (34.5\%), which may be related to the fact that these bats have higher levels of activity in human settlements, forest remnants, monocultures and near the presence of artificial lights (Jung and Kalko 2010; Rydell 2006). Blood consumption was cited by 60 respondents $(30.5 \%)$, with the belief that all bats feed on blood, and attack goats, horses, and cows $(30.5 \%$, Figure $2 \mathrm{~b})$. The tropical dry forest of Tolima has only two hematophagous species (D. rotundus and D. youngii) of the 55 species of bats registered for this area (García-Herrera et al. 2019a). In areas where attacks on domestic animals occur, people tend to generalize and stigmatize all bats as hematophagous, causing death and persecution of them (Cordero-Schimidt 2012). Frugivory was the third most reported diet at $27.4 \%$ (Sheherazade et al. 2017), but the respondents probably do not realize that Neotropical fruit bats (Phyllostomidae) are important seed dispersers of at least 549 plant species with high ecological and economic value according to the latest reviews (Ramírez-Fráncel et al. 2021; Scanlon et al. 2014).

For overall fur color and external appearance, most respondents said that bats are black $82(41.6 \%)$, possibly related to their nocturnal habits, whereas 53 

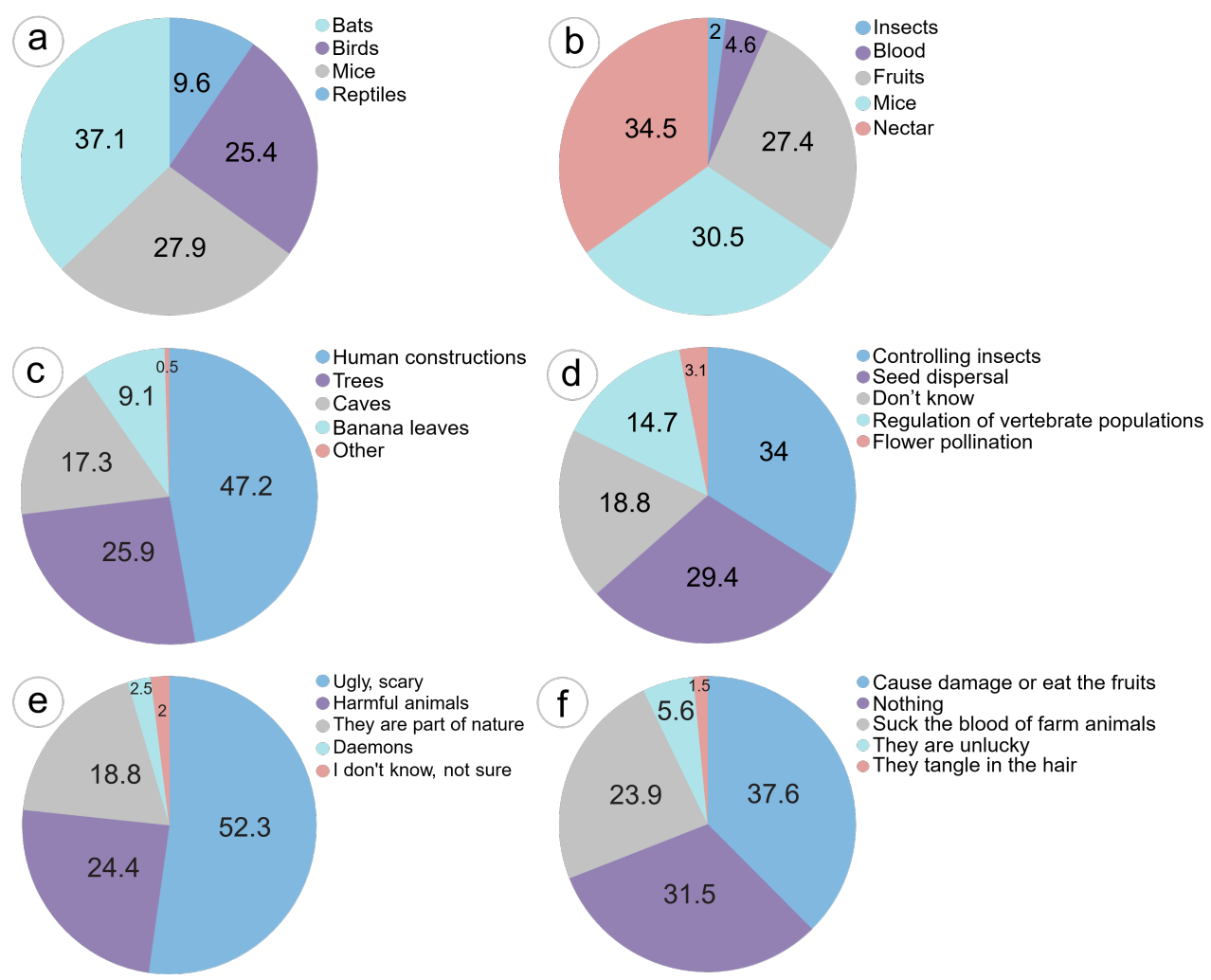

Figure 2. Percentage distribution of the responses between the surveyed communities on human-bat interactions in the tropical dry forest (TDF) areas from Tolima, Colombia. a. recognized taxonomic position, b. feeding habits, c. roosting, d. ecosystem services provided, e. beliefs, and f. general perceptions.

(26.9\%) and $52(26.4 \%)$ reported brown and gray, respectively (Table 1). People identify that bats are associated with dark places, similar to studies in Argentina and Brazil (e.g., Gomes et al. 2017; Castilla et al. 2020). For roosts, $93(47.2 \%)$ people identified that bats commonly live in human structures, such as abandoned houses, bridges or tunnels, and 51 people $(25.9 \%)$ identified trees as a type of roost, while the remaining percentage mentioned that bats can live in caves, banana leaves, and other places (Figure 2c).

When asked about the ecosystem services provided by bats, $67(34 \%)$ and 58 (29.4\%) people mentioned insect predation and seed dispersal, respectively, whereas only $6(3.1 \%)$ of respondents mentioned pollination (Figure 2d). The interviewees noted the seeds and fruits from the remains of feces that are observed on the floor of their houses and close to the plants that serve as shelters for bats. Therefore, many surveyed people knew of this key environmental service (seed dispersal) that bats perform. Pollination is another essential ecosystem service, however, most of the respondents do not know or are not sure about this service. Our study found that the community was unaware of the importance of bats to the provision of any ecosystem services (18.8\%, Table 1). These results are of concern because even though bats are fundamental to the functioning of natural and modified landscapes, there are misconceptions that have led to the underestimation of the ecological roles that bats play (Boyles et al. 2011; Kalka et al. 2008; Kemp et al. 2019), as well as the lack of information on some basic concepts and services that this group fulfills (Ramírez-Fráncel et al. 2021).

Previous studies have found that, in general, people's perception about bats is mostly negative and is related to the appearance of these animals and their coloration (Castilla and Viñas 2012; Castilla et al. 2020; Prokop and Tunnicliffe 2008). However, in the present study, $69 \%$ of people had positive perceptions of bats, and classified them as a part of nature or as animals that do not disturb humans. This positive perception increases with the age of people and those who have completed secondary education or have university education (Table 1 ).

\section{Use and cultural beliefs of bats}

Two people in the municipality of Ambalema (1\%) knew a use of bats in traditional medicine for the treatment of asthma, whereby bats are roasted, then pulverized into ashes and placed on the patient's chest. This is a use similar to that reported in north- 
Table 3. Significant results of the Generalized Linear Model (GLM) to the response variable perception of bats by people in Tolima, Colombia.

\begin{tabular}{|c|c|c|c|c|c|}
\hline Question & Cofactor & Estimate & Stand error & t -value & $\mathbf{P}(>|t|)$ \\
\hline \multirow{2}{*}{ Taxonomic position of bats } & Ethnic origin & 6.58 & 1.04 & 6.30 & $<0.007$ \\
\hline & Education level & 9.66 & 9.29 & 10.39 & $<0.002$ \\
\hline \multirow{3}{*}{ Feeding habits of bats } & Gender & 2.70 & 7.81 & 3.45 & $<0.008$ \\
\hline & Education level & 1.00 & 1.64 & 6.13 & $<0.008$ \\
\hline & Ethnic origin & 3.03 & 1.12 & 2.70 & 8 \\
\hline \multirow{3}{*}{ Bats's color } & Gender & 3.22 & 9.57 & 3.36 & 1 \\
\hline & Education level & -1.00 & 2.21 & -4.52 & $<0.001$ \\
\hline & Job types & -3.56 & 2.86 & -12.42 & $<0.002$ \\
\hline \multirow{3}{*}{ Species present in the area } & Ethnic origin & -9.64 & 1.10 & -8.79 & $<0.003$ \\
\hline & Education level & 4.39 & 1.31 & 3.34 & 1 \\
\hline & Job types & -1.21 & 3.90 & -3.09 & 2 \\
\hline Type of diseases they transmit & Job types & -8.12 & 7.51 & -10.81 & $<0.002$ \\
\hline \multirow{4}{*}{ Roosts used by bats } & Gender & 3.29 & 1.03 & -3.20 & 1 \\
\hline & Ethnic origin & 3.59 & 1.10 & 3.26 & 1 \\
\hline & Education level & 7.21 & 1.40 & 5.16 & $<0.001$ \\
\hline & Job types & 1.12 & 1.48 & 7.53 & $<0.001$ \\
\hline \multirow{3}{*}{ Services provided by bats } & Gender & -3.14 & 8.85 & -3.55 & $<0.005$ \\
\hline & Ethnic origin & -6.30 & 1.34 & -4.70 & $<0.007$ \\
\hline & Education level & 1.45 & 3.38 & 4.28 & $<0.004$ \\
\hline Local uses related to bats & Gender & 1.14 & 2.04 & 5.59 & $<0.001$ \\
\hline $\begin{array}{l}\text { What degree of closeness have } \\
\text { you had with a bat? }\end{array}$ & Gender & 1.65 & 8.07 & 2.04 & 43 \\
\hline How are bats extracted from & Education level & -3.70 & 8.11 & -4.56 & $<0.001$ \\
\hline human structures? & Job types & 3.83 & 3.41 & 11.24 & $<0.002$ \\
\hline \multirow{2}{*}{$\begin{array}{l}\text { If a bat has been touched. how do you } \\
\text { protect yourself and catch them? }\end{array}$} & Education level & -6.53 & 2.04 & -32.04 & $<0.002$ \\
\hline & Job types & -3.54 & 7.94 & -4.45 & $<0.002$ \\
\hline Possible damage caused by bats & Gender & 5.14 & 1.37 & 3.76 & 4 \\
\hline \multirow{3}{*}{ Local myths or beliefs related to bats } & Gender & 9.02 & 9.71 & -9.29 & $<0.002$ \\
\hline & Education level & 7.57 & 2.26 & -3.35 & 1 \\
\hline & Job types & 2.97 & 5.97 & 4.98 & $<0.002$ \\
\hline \multirow{2}{*}{ Animals that should be conserved } & Education level & 3.91 & 1.07 & 3.65 & $<0.004$ \\
\hline & Job types & -2.44 & 8.13 & -2.99 & 3 \\
\hline
\end{tabular}

eastern Brazil, where some use bats in the treat- ment of alcoholism, asthma and as a contraceptive 
for livestock (Da Costa Rego et al. 2015). Guano used as fertilizer was also mentioned by the interviewees, although to a lesser extent and with various uses $(12.2 \%)$. This differs from that reported in other investigations where people use guano as a fertilizer on a larger scale, such as in Tucumán, Argentina (Castilla et al. 2020). However, the use of bats should be considered a major concern, as many emerging zoonotic infectious diseases have been linked to bats, as potential reservoirs for different viruses (Banerjee et al. 2019; Olival et al. 2014; Paige et al. 2014). Unfortunately, with the current coronavirus pandemic and emerging infectious diseases, the conflicts between humans and bats are further affecting the mostly negative perception of these animals (Ramos Pereira et al. 2020). Despite the fact that in our study there is no use of bats as a source of protein, as is the case in Brazilian communities (Riccucci 2012; Ziment and Tashkin 2000), it is evident that this will not be enough to change negative attitudes (see Figure 3 below). It is necessary to reinforce positive aspects of bats with concrete information and practices towards society that allow the conservation and protection of this important group of wildlife (see educational alternatives by Ramírez-Fráncel et al. 2021).

Regarding beliefs and perceptions, 103 (52.3\%) mentioned that bats are ugly and generate fear; and $48(24.4 \%)$ people declared that they are harmful. However, only a small number of people 5 (2.5\%) affirmed that the bats were demonic or representative of the devil. Our analyses showed that fear or aversion towards them was significantly different from other answers (good or at least harmless), as shown by $t$ tests $(\mathrm{p}<0.001)$. A total of 15 people, including some who lost domestic animals, said they were proud that bats live in their mountains and believe that they can also coexist with them and that their negative perception cannot hide their value in ecosystem services.

The GLM analysis showed that people's attitudes towards bats were likely determined by gender (male), level of education (low to medium), and type of employment (non-formal) (Table 2). Bats have been represented in the pre-Hispanic goldsmithing of Colombia, characterized in the use of nasal appendages and specific teeth that sometimes extend exaggeratedly out of the face, as observed in the indigenous groups Calima, Cauca, Quimbaya, Tolima, Urabá, Sinú, Tairona and Muisca (Gault 2012). More recently, however, bats have been associated with the negative image of Dracula that is depicted in movies. The interviewees also mentioned the myths that bats smoke cigarettes or tobacco 32 (16.2\%), 55 (27.9\%) that they are the product of a pact between God and the devil, and 110 (55.8\%) that they are blind (Table 1). These myths have led to a bad reputation for bats, causing fear and potentially threatening them.

\section{Human-bat interactions}

In general, respondents had a positive attitude of bats with 136 (69\%) people classifying them as part of nature, whereas 61 (31\%) people had a negative perception related to aesthetic value, such as classifying them as ugly. In terms of previous experiences, 126 interviewees $(64 \%)$ have lived in close proximity to bats in their homes or at work, $60(30.4 \%)$ declared that bats frequent trees near their home, and 11 (5.6\%) have touched a bat. To remove bats from their work or home, $104(52.8 \%)$ people used rags, whereas the remainder had used smoke from firewood, a broom, or turned on the light. The use of non-lethal methods to exclude bats was a positive attitude that could be related to the inhabitants' relationship with nature (Serpell 2004).

To assess risk, we inquired about the care taken at the time of manipulating bats; $85(43.1 \%)$ people used gloves, a plastic bag or rag to catch them, 51 (25.9\%) used a broom, $12(6.1 \%)$ used sticks or tweezers, and $49(24.9 \%)$ had not taken any precautions (see Table 1). The GLM analysis showed an explanatory effect related to the level of education and the type of employment. Respondents such as farmers or housewives used non-aggressive techniques to exclude them from homes. In terms of human health, $172(89.3 \%)$ people recognized that bats could transmit viruses and bacteria. For myths, $74(37.6 \%)$ respondents indicated that bats caused damage to fruit, whereas 11 (23.9\%) indicated that bats feed on the blood of cattle, sheep, horses, goats and pigs. Lower percentages indicated that bats are a symbol of bad luck or get entangled in hair, but $31 \%$ had no myths related to bats (Figure $2 \mathrm{f}$ and Figure 3).

The handling of bats is also a cause for concern because as detected in this study and others carried out in Argentina and Brazil (Castilla and Viñas 2012; Castilla et al. 2020; Gomes et al. 2017), increasing the chances of being bitten can potentially lead to a zoonosis. Exclusion protocols that are endorsed by academics and conservation groups in Colombia are required. Based on other studies (Barnes 2013; Castilla and Viñas 2012; Cousins and Compton 2005), bats are associated with the transmission of rabies (Figure 3) and the interviewees in our study recognized that more precautions are needed when they come in contact with bats.

When asked about the species of animals in the study area that should be conserved, the highest percentages were for birds and small species of wild cats such as oncilla (Leopardus tigrinus). Bats were ranked fourth with $8.1 \%$ of the responses. People seem to recognize the ecological functions of bats, but they are unaware of their vulnerability and conservation importance. Therefore, an environmental educa- 


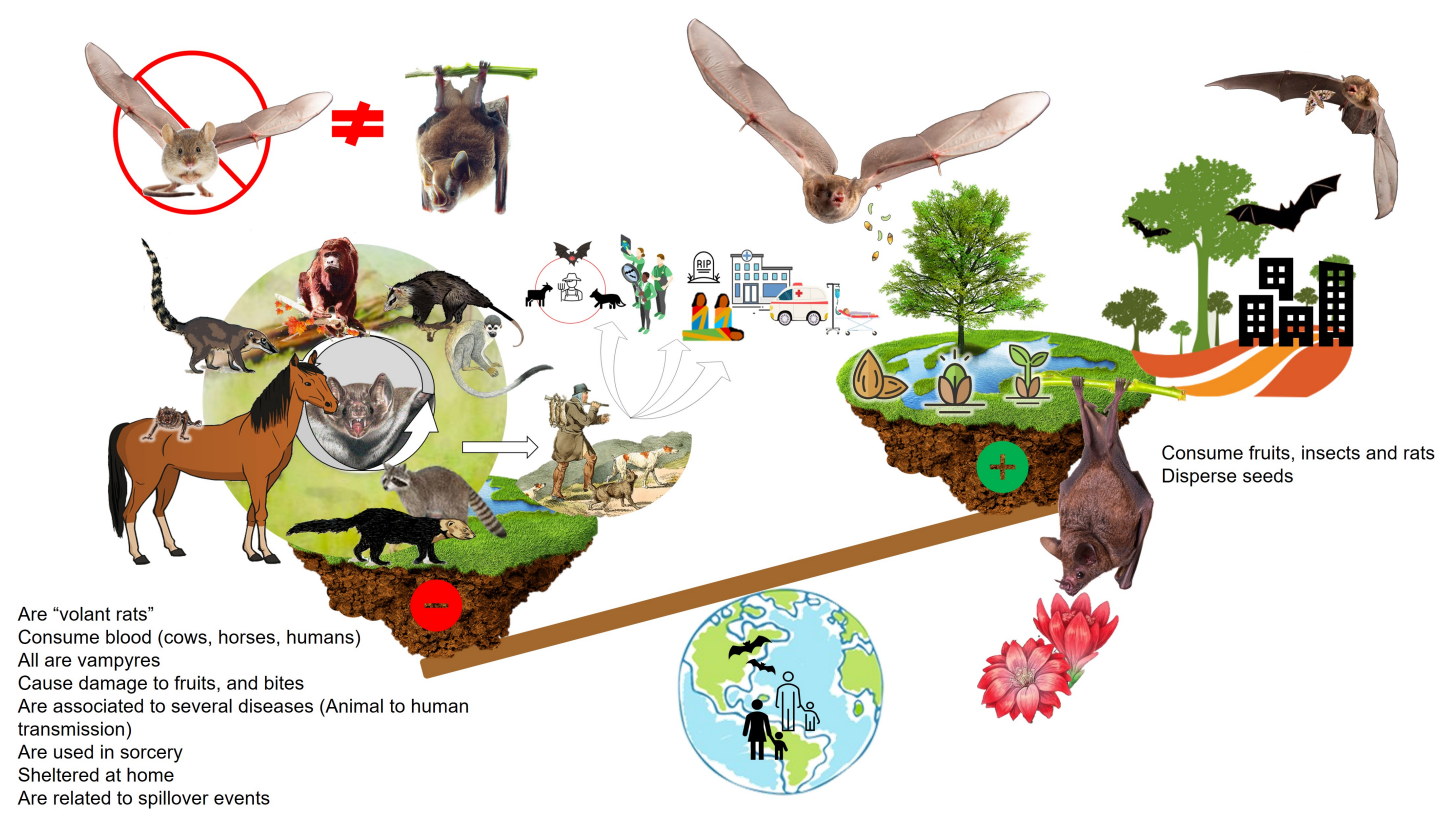

Figure 3. Generalized perceptions and attitudes (positive vs. negative) of people about bats in central Colombia. Notice that the scale is tilted towards negative perceptions related to opinions that people perceive of wildlife and farmland animals, and potential diseases that can be transmitted from bats to humans. This situation contrasts with the positive aspects that people recognize selected ecosystem services provided by bats. However, despite that most people perceive negative aspects of bats, we found that most of the people interviewed have some positive perception of them.

tion intervention program is required in order to publicize the importance of bats as a regulator of ecosystems (Kemp et al. 2019; Kunz et al. 2011; Medellin et al. 2017).

To change attitudes and increase awareness of the ecosystem services provided by wildlife, including bats, strategies need to involve local communities, politicians, administrators, and researchers which all have different scales of values, knowledge and interests vital to achieve lasting environmental sustainability (Altieri and Toledo 2011). Therefore, this study constitutes the basis for building environmental education strategies that allow the construction of an action plan for the conservation of a poorly understood fauna, such as bats.

The analysis of cross-cultural perceptions of bats and their interactions with humans in the tropical dry forest of Tolima (Quiroga-C et al. 2019) represents a relatively small survey sample, but forms a baseline for further study. Unfortunately, human-wildlife assessments in the TDF are typically not available for larger areas, especially considering that habitat destruction and the resultant fragmentation of the remaining forest are a common phenomenon in Colombia (García-Herrera et al. 2015; Quiroga-C et al. 2019; Villanueva et al. 2015). Understanding these limitations will contribute to identify which characteristics influence human-wildlife interactions, so as to improve our comprehension of the relationship between the perceptions of people about bats and the ecosystem services they provide. Conservation strategies for the tropical dry forest should be linked to the conservation of bats because these unique flying mammals will be important components of sustaining these dynamic landscapes as human perceptions change over time (Dou et al. 2020).

\section{Promoting the conservation of bats in the Colombian tropical dry forests and elsewhere}

Many societies have a bad concept of bats, based mainly on myths, legends and movies related to vampires. In addition, bats are believed to transmit or cause diseases, not only rabies, but also allergies and respiratory problems such as asthma caused by guano that may accumulate under the roofs where colonies of bats live. Furthermore, poorly managed and misinterpreted COVID-19 pandemic information, as well as emerging infectious diseases, is going to increase the negative perception of these animals (Figure 3 ).

However, the interviewed inhabitants have the perception that the bat population has increased in the last five years, due to actions such as the prohibition of logging and recognition of almost 27,000 
hectares as conservation areas in the TDF of the Department of Tolima. These actions tend to favor bats with an abundant food and forest remnants where they can find shelter and food (García-Herrera et al. 2019a; García-Herrera et al. 2019b; García-Herrera et al. 2020).

Nature and scientific tourism are activities that are beginning to develop both nationally as well as regionally, so there are optimistic expectations that motivate the rural community where bats have become an obligatory topic in their strategies to attract tourists. Locally, it is also about strengthening actions to keep bats in the forests, including the promotion of environmental education initiatives or programs for the local people and visitors. The communities have supported researchers and students of different educational levels to carry out field work or short stays (as for the first authors, popularly known as the "Leidys") in their territories (Alves and Souto 2015).

The conservation of bats requires the assistance of local people. However, the future of bats and their habitats depends on the support that is channeled to the communities, so that they can improve their standards of living. It is also important to strengthen the social support and organization of other neighboring communities because bats are species that need a large area to function due to their vagility (GarcíaHerrera et al. 2019; Ramírez-Fráncel et al. 2015; Ramírez-Fráncel et al. 2018; Ramírez-Fráncel et al. 2020). Only in this way can a management plan for the conservation of bats be integrated at the regional level. Although several proposals for the conservation of bats have gotten global attention (e.g., RamírezFráncel et al. 2021), many lack economic support to make them viable. It is a situation of major concern in vulnerable areas, especially inmegadiverse countries, such as Colombia, and under the current or potential future pandemic.

\section{CONCLUSION}

In general, the perception of people about bats varied according to the gender and level of education of the interviewees in Tolima, Colombia. There were positive perceptions of bats despite a dominance of negative attitudes. Further efforts should be made in the transmission and dissemination of knowledge about the ecological importance of bats, which will contribute to the success of future conservation plans in the area with the participation of the local community.

Although there was a general lack of knowledge of the tropical dry forest and the biological and ecological aspects of bats, some people recognized basic information about the habitat requirements of bats within the study area, such as roosts in building, which could help identify potential priority conservation areas based on controllable human-bat interactions. Even in cases of conflict between local people and bats, the actions of the communities have been fundamental to maintain conservation processes and peaceful interaction. This can be strengthened by the increased participation of government agencies related to the preservation of biodiversity and other key stakeholders such as conservationists, consultants, and academics. Currently, there is a new paradigm shift occurring for the conservation of bats, which implies having a strong social participation at the community level. But it must also be recognized that there is a large information gap in the role that humans play in biological conservation in vulnerable areas and megadiverse countries such as Colombia.

\section{ACKNOWLEDGEMENT}

We are thankful to the residents of Alvarado, Armero-Guayabal, Ambalema, Ibagué and San Sebastián de Mariquita municipalities who welcomed us and allowed us to interview them. We thank the members of the Grupo de Investigación en Zoología (GIZ) for their help with the field work and the Oficina de Investigaciones y Desarrollo Científico (Convocatoria 004-2017) to finance research projects from the University of Tolima. The first and second authors thank to Minciencias, Convocatoria 755 de 2016 for the scholarships to advance their doctoral studies. We would like to thank the anonymous reviewers for their suggestions and comments that improved greatly the final version of the manuscript.

\section{DATA AVAILABILITY}

The data used to support the findings of this study are available from the corresponding author upon reasonable request.

\section{CONFLICT OF INTEREST}

The authors have no conflicts of interest to declare.

\section{CONTRIBUTION STATEMENT}

Conceived of the presented idea: LARF

Carried out the experiment: LARF, LVGH

Carried out the data analysis: LVGH, LARF

Wrote the first draft of the manuscript: LVGH, LARF, GG

Review and final writing of the manuscript: GG, SLP, BKL, FANV, GRF

Supervision: BKL, GG. 


\section{REFERENCES}

Albuquerque UP, Lucena RFP, Cunha LVFC, Alves RRN (2014) Methods and techniques in ethnobiology and ethnoecology. Springer Protocols Handbooks. Berlin. Springer.

Albuquerque UP, Brito AL, Nascimento ALB, Oliveira AFM, Quixabeira CMT, Dias DdQ, Lira EC, Silva FS, Delmondes GdA, Coutinho HDM, Barbosa MO, Landell MF, Alves RRN, Ferreira Júnior, WS (2020) Medicinal plants and animals of an important seasonal dry forest in Brazil. Ethnobiology and Conservation 9(8):1-53. doi: 10.15451/ec2020-03-9.08-1-53

Alonso Morales LA (2013) Caracterización de la población humana de los departamentos de Tolima y Huila perspectivas: demográficas, genéticas y socioculturales. Master Thesis. Universidad Nacional de Colombia.

Alonso Morales LA, Casas-Vargas A, Rojas Castro M, Resque R, Ribeiro-dos-Santos ÂK, Santos S, Gusmão L, Usaquén W (2018) Paternal portrait of populations of the middle Magdalena River region (Tolima and Huila, Colombia): New insights on the peopling of Central America and northernmost South America. PLoS ONE 13(11):e0207130.

Altieri M, Toledo VM (2011) The agroecological revolution of Latin America: rescuing nature, securing food sovereignty and empowering peasants. The Journal of Peasant Studies 38(3):587-612.

Alves RRN (2012) Relationships between fauna and people and the role of ethnozoology in animal conservation. Ethnobiology and Conservation 1(2): 1-69. doi: 10.15451/ec2012-8-1.2-1-69

Alves RRN, Souto WMS (2015) Ethnozoology: A Brief Introduction. Ethnobiology and Conservation 4(1):1-13. doi: 10.15451/ec2015-1-4.1-1-13

Banerjee A, Kulcsar K, Misra V, Frieman M, Mossman K (2019) Bats and Coronaviruses. Viruses 11(1):1-41.

Barnes P (2013) Battitude: An assessment of human attitude and behaviour towards the critically endangered Pteropus rodricensis. Doctoral Thesis. Imperial Collage London.

Berkes F (2008) Sacred Ecology. 2a . Edition, Routledge, New York.

Boyles JG, Cryan PM, McCracken GF, Kunz TH (2011) Economic importance of bats in agriculture. Science 332(6025):41-42.
Burneo S, Proaño MD, Tirira DG (2015) Plan de acción para la conservación de los murciélagos del Ecuador. Quito: Programa para la Conservación de los Murciélagos del Ecuador. Ministerio del Ambiente del Ecuador. Ecuador.

Castilla MC, Viñas M (2012) Percepción sobre murciélagos urbanos y su manejo en San Fernando del Valle de Catamarca, Argentina. In Comunidad de Manejo de Fauna Silvestre (COMFAUNA). Memorias del X Congreso Internacional de Fauna Silvestre de América Latina, Salta, Argentina, pp. 15.

Castilla MC, Campos CM, Colantonio SE, Díaz MM (2020) Perceptions and attitudes of the local people towards bats in the surroundings of the big colony of Tadarida brasiliensis, in the Escaba dam (Tucuman, Argentina). Ethnobiology and Conservation 9(9):1-14. doi: 10.15451/ec202003-9.09-1-14

Castro A, Galindo J (2009) Murciélagos en el México de ayer y hoy. Revista de Divulgación Científica y Tecnológica de la Universidad Veracruzana 22:53-56.

Cimadamore A, Eversole R, McNeish JA (2006) Pueblos indígenas y pobreza. Enfoques multidisciplinarios. CLACSO. Buenos Aires. Argentina.

Cordero-Schimidt E (2012) Educación ambiental en la Reserva Biológica La Tirimbina. Biocenosis 26:45-52.

Cousins JA, Compton SG (2005) The Tongan flying fox Pteropus tonganus: status, public attitudes and conservation in the Cook Islands. Oryx 39(2):196-203.

Da Costa Rego KM, Zeppelini CG, Lopez LCS, Alves RRN (2015) Assessing human-bat interactions around a protected area in northeastern Brazil. Journal of Ethnobiology and Ethnomedicine 11(80):1-8.

De la Ossa-Lacayo A, De la Ossa J (2012a) Utilización de fauna silvestre en el area rural de Caimito, Sucre, Colombia. Revista Colombiana Ciencia Animal, RECIA 4(1):46-58.

De la Ossa-Lacayo A, De la Ossa J (2012b) Índice del valor de uso para la fauna silvestre en la región del San Jorge Mojana Sucrena, Colombia. Revista Colombiana Ciencia Animal, RECIA 4(2):308-319.

Dichdji A (2017) Naturaleza y Cultura: Diálogos Interdisciplinarios Entre La Historia Ambiental y la Antropología. Luna Azul 44:277-293. 
Drummond SM (2004) Morcegos: verdades e mitos. Uma análise acerca do conhecimento sobre os morcegos na sociedade: folclore, realidade e cultura. Thesis. Universidade Estadual do Sudoeste da Bahia.

Drumond MA, Giovanett L, Guimarães A (2009) Técnicas e Ferramentas Participativas para a Gestão de Unidadesde Conservação. Programa Áreas Protegidas da Amazônia. ARPA e Cooperação Técnica Alemã-GTZ. Brazil.

García-Herrera L, Ramírez-Fráncel L, Reinoso Flórez G (2018) Potential distribution of Sphaeronycteris toxophyllum in Colombia and new record. Therya $9(3): 255-260$.

García-Herrera LV, Ramirez-Francel LA, LosadaPrado S, Reinoso-Florez G, Villa-Navarro FA, Guevara $G$ (2020) Functional traits of bats associated with the use of wetlands in Colombian tropical dry forests. Acta Chiropterologica 22(2):283-294.

García-Herrera LV, Ramirez-Francel LA, ReinosoFlorez G (2015) Mamíferos en relictos de bosque seco tropical del Tolima, Colombia. Mastozoologia Neotropical 22(1):11-21.

García-Herrera LV, Ramirez-Francel LA, ReinosoFlorez G (2019a) Mamíferos del departamento del Tolima: distribución y estado de conservación. Revista U.D.C.A Actualidad \& Divulgación Cientifica 22(2):e1100.

García-Herrera LV, Ramirez-Francel LA, ReinosoFlorez G (2019b) Consumo de plantas pioneras por murciélagos frugívoros en un fragmento de bosque seco tropical (Colombia). Ciencia en Desarrollo 10:33-41.

Gobernación del Tolima and Universidad del Tolima (2016) Caracterización de la población Afrodescendiente y Rom del departamento del Tolima - "Por un Tolima diverso, multicultural e incluyente". Ibagué. Colombia.

Gomes MDCB, Costa-Neto EM, Álvarez MRDV (2017) Ethnozoology of bats (Mammalia, Chiroptera) in Feira de Santana Municipality, Bahia State, Northeastern Brazil. Brazilian Journal of Biological Sciences 4(7):147-156.

Gault E (2012) El hombre y el animal en la Colombia prehispánica. Estudio de una relación en la orfebrería. Boletín del museo chileno de arte precolombino 17(1):11-30.

International Society of Ethnobiology (2006) International Society of Ethnobiology Code of Ethics. International Society of Ethnobiology. [http://www. ethnobiology . net/what-we-do/core-programs / ise-ethics-program/code-of-ethics] Accessed 1 January 2015.

Jung K, Kalko EKV (2010) Where forest meets urbanization: foraging plasticity of aerial insectivorous bats in an anthropogenically altered environment. Journal of Mammalogy 91(1):144-153.

Kalka MB, Smith AR, Kalko EKV (2008) Bats limit arthropods and herbivory in a tropical forest. Science 320(5872):71.

Kemp J, López-Baucells A, Rocha R, Wangensteen OS, Andriatafika Z, Nair A, Cabeza M (2019) Bats as potential suppressors of multiple agricultural pests: A case study from Madagascar. Agriculture, Ecosystems and Environment 269(1):88-96.

Kunz TH, De Torrez EB, Bauer D, Lobova T, Fleming TH (2011) Ecosystem services provided by bats. Annals of the New York Academy of Sciences 1223(1):1-38.

Mantilla-Meluk H, Cadena G, Jiménez-Ortega AM (2014) Historia de la mastozoología en Colombia: Pasado, presente y perspectivas. In: Ortega J, Martínez JL, Tirira DG (eds) Historia de la mastozoología en Latinoamérica, las Guayanas y el Caribe. Editorial Murciélago Blanco y Asociación Ecuatoriana de Mastozoología, Quito y México, DF. pp. 233-250.

Medellin RA, Wiederholt R, Lopez-Hoffman L (2017) Conservation relevance of bat caves for biodiversity and ecosystem services. Biological Conservation 211:45-50.

Melathopoulos AP, Cutler GC, Tyedmers P (2015) Where is the value in valuing pollination ecosystem services to agriculture? Ecological Economics 109:59-70.

Millennium Ecosystem Assessment (2005) Ecosystems and Human Well-being: Synthesis. Island Press, Washington, DC.

Moya I, Pacheco L, Aguirre L (2015) Relación de los ataques de Desmodus rotundus con el manejo del ganado caprino y algunas características del hábitat en la Prepuna de Bolivia. Mastozoología Neotropical 22(1):73-84.

Osbahr K, Morales N (2012) Conocimiento local y usos de la fauna silvestre en el municipio de San Antonio de Tequendama (Cundinamarca, Colombia). Revista U.D.C.A Actualidad 85 Divulgacion Cientifica 15(1):187-197.

Parra HJP, Silva-R A, Estrada-C G (2015) Etnozo- 
ologia de la fauna silvestre por indígenas ingas al sur Occidente del departamento del Caqueta en el piedemonte amazónico colombiano. In: Monroy MR, Garcia FA, Pino MJM and Costa NME (eds) Saberes etnozoologicos latinoamericanos UEFS, Brasil, pp.187-204.

Prokop P, Tunnicliffe SD (2008) Disgusting animals: Primary school children's attitudes and myths of bats and spiders. Eurasia Journal of Mathematics, Science and Technology Education $4(2): 87-97$.

Prokop P, Randler C (2018) Biological predispositions and individual differences in human attitudes toward animals. In: Alves RRN, Albuquerque UP (eds) Ethnozoology: animals in our lives. Elsevier, London, pp. 447-466.

Pizano C, Garcia H (2014) El Bosque Seco Tropical en Colombia. Instituto de Investigacion de Recursos Biologicos Alexander von Humboldt (IAvH). Bogota, D.C. Colombia.

Quiroga-C JA, Roa-R HY, Melo O, Fernández-M F (2019) Estructura de fragmentos de bosque seco tropical en el sur del departamento del Tolima, Colombia. Boletín Científico, Centro de Museos, Museo de Historia Natural 23(1):31-51.

R Core Team (2020) R: A Language and Environment for Statistical Computing; Version 3.5.3. R Foundation for Statistical Computing: Vienna, Austria; [www.R-project.org] Accessed 5 May 2021.

Ramírez-Fráncel LA, García-Herrera LV, ReinosoFlórez G (2015) Nuevo registro del murciélago pálido Phylloderma stenops (Phyllostomidae); en el valle alto del río Magdalena, Colombia. Mastozoología Neotropical 22:97-102.

Ramírez-Fráncel LA, García-Herrera LV, ReinosoFlórez G (2020) Using MaxEnt modeling to predict the potential distribution of Platyrrhinus ismaeli (Phyllostomidae). Therya 11(2):203-212.

Ramírez-Fráncel LA, García-Herrera LV, ReinosoFlórez G (2018) First record of Platyrrhinus albericoi Velazco, 2005 (Chiroptera, Phyllostomidae) in the eastern slope of the Central Andes of Colombia. Check List 14(6):1161-1167.

Ramírez-Fráncel LA, García-Herrera LV, LosadaPrado S, Reinoso Flórez G, Sánchez-Hernández A, Estrada-Villegas S, Lim BK, Guevara G (2021) Bats and their vital ecosystem services: A global review. Integrative Zoology doi: 10.1111/17494877.12552.
Ramos FG, González JJ, Guadarrama-Overa F, Eichenberger R, Bermúdez DW (2007) El Jaguar de la Luz: Solucionando el Conflicto JaguarGanado para Conservar La Biodiversidad. In: II Simposio Biodiversidad de Oxaca: Una visión Integral de los Recursos Naturales en Oaxaca. CIIDIROaxaca, Instituto Politécnico Nacional, Oaxaca, México.

Retana-Guiascón OG, Navarijo-Ornelas ML (2012) Los valores culturales de los murciélagos. Revista Mexicana de Mastozoología 2(1):18-26.

Riccucci M (2012) Bats as materia medica: an ethnomedical review and implications for conservation. Vespertillio 16:249-270.

Rigby RA, Stasinopoulos DM (2005) Generalized additive models for location, scale and shape. Royal Statistical Society 54(3):507-554.

Rodríguez-Posada ME, Morales-Martínez DM, Ramírez-Chaves HE, Martínez-Medina D, CalderónAcevedo CA (2021) A new species of Long-eared Brown Bat of the genus Histiotus (Chiroptera) and the revalidation of Histiotus colombiae. Caldasia 43(2):221-234.

Rojas W, Parra MY, Campo O, Caro MA, Lopera JG, Arias W, Duque C, Naranjo A, García J, Vergara C, Lopera J, Hernández E, Valencia A, Caicedo Y, Cuartas M, Gutiérrez J, López S, Ruiz-Linares A, Bedoya G (2010) Genetic Makeup and Structure of Colombian Populations by Means of Uniparental and Biparental DNA Markers. American Journal of Physical Anthropology 143(1):13-20.

Rondón F, Osorio JC, Peña ÁV, Garcés HA, Barreto G (2008) Diversidad genética en poblaciones humanas de dos regiones colombianas. Colombia Médica 39:52-60.

Russo D, Bosso L, Ancillotto L (2018) Novel perspectives on bat insectivory highlight the value of this ecosystem service in farmland: Research frontiers and management implications. Agriculture, Ecosystems and Environment 266:31-38.

Rydell J (2006) Bats and their insect prey at streetlights. In: Longcore RC (eds) Ecological consequences of artificial night lighting. Island Press, Washington, pp. 43-60.

Salgado López H, Varón Barbosa M (2019) Early prehispanic settlement in the Magdalena Valley in Tolima, Colombia. Balance and perspectives. Quaternary International 505:55-68.

Scanlon AT, Petit S, Tuiwawa M, Naikatini A (2014) 
High similarity between a bat-serviced plant assemblage and that used by humans. Biological Conservation 174:111-119.

Serpell J (2004) Factors influencing human attitudes to animals and their welfare. Journal of Animal Welfare 13:145-151.

Sheherazade Y, Pradana DH, Tsang SM (2017) The role of fruit bats in plant community changes in an urban forest in Indonesia. Raffles Bulletin of Zoology 65:497-505.

Torres DF, Oliveira ES, Alves RRN (2018) Understanding Human-Wildlife Conflicts and Their Implications. In: Alves RRN, Albuquerque UP (eds) Ethnozoology: animals in our lives. Elsevier, London, pp. 421-445.

Torres J, Fernández A (2012) Instrumento para el análisis y evaluación de los conocimientos, actitudes y acciones hacia los murciélagos en la Mixteca poblana. Investigación Ambiental Ciencia y Política Pública 4:4-18.
Van Toor ML, O'Mara MT, Abedi-Lartey M, Wikelski M, Fahr J, Dechmann DK (2019) Linking colony size with quantitative estimates of ecosystem services of African fruit bats. Current Biology 29(7):R237-R238.

Villanueva B, Melo O, Rincón M (2015) Estado del conocimiento y aportes a la flora vascular del bosque seco del Tolima. Colombia Forestal 18(1):9-23.

Ziment I, Tashkin DP (2000) Alternative medicine for allergy and asthma. The Journal of Allergy and Clinical Immunology 106(4):603-614.

Received: 01 June 2020

Accepted: 29 July 2021

Published: 15 October 2021

Editor: Rômulo Alves 